\title{
MACHINE-GENERATED DISPLAYS OF WELL LOGS AND LITHOLOGY \\ FROM SELECTED WELLS ON THE NORTH SLOPE OF ALASKA: \\ SEVEN WELLS FROM THE EAST-CENTRAL NORTH SLOPE
}

\section{By}

Kenneth J. Bird

U.S. Geological Survey

Menlo Park, California

Open-File Report

81-1036

This report is preliminary and has not been reviewed for conformity with U.S. Geological Survey editorial standards and stratigraphic nomenclature.

Menlo Park, California

August 1981 


\title{
MACHINE-GENERATED DISPLAYS OF WELL LOGS AND LITHOLOGY FROM SELECTED WELLS ON THE NORTH SLOPE OF ALASKA: SEVEN WELLS FROM THE EAST-CENTRAL NORTH SLOPE
}

\author{
By \\ Kenneth J. Bird \\ U.S. Geological Survey \\ Menlo Park, California
}

\section{INTRODUCTION}

Mechanical well $\mathrm{log}$ and lithology information stored on magnetic tape is used to produce computer-generated plots which offer a compact summary (display) of multiple log curves and rock types. This paper is one of a series concerning displays for 82 North slope Alaska wells, and provides background information on the displays, location of the wells, details of modifications to the original log curves, origin of the lithology column, and explanation of the symbols. These displays, designed by L. B. Magoon and myself, are products of a contract between the U.S. Geological survey and Petroleum Information Corporation (PI).

These 82 North Slope well displays, 70 of which are from the National Petroleum Reserve in Alaska (NPRA), are being released in a series of six open-file Reports by this author. Five of these reports, now available, include 69 displays. A sixth report, with the remaining 13 well displays, awaits completion in late summer 1981. This particular report of the series presents 7 displays from the east-central North slope (plates 1-7) located on the map (fig. 1) and tabulated on the list (table 1).

\section{DISPLAY}

The display format shows a heading positioned above a lithologic column which is flanked on the left by gamma-ray and spontaneous potential curves, and on the right by resistivity, sonic, density, and differential caliper curves. The vertical scale is $1 \mathrm{in}$. per $100 \mathrm{ft}$. An overall width of $9.5 \mathrm{in}$. allows the display to be printed on commercial log paper. The generalized format is designed to be compatible with a variety of applications including correlation (see Tetra Tech, Inc., 1980, Geologic Report) and other data displays (see geochemical displays of Magoon and Claypool, 1980). The reduced scale precludes engineering calculations, but the digital form of the data allows plotting at any desired scale. Magnetic tape with the digital data is available from PI in Denver, Colorado. All log curves have been digitized from paper logs, or, on more recent wells, recorded digitally at the well site. Depth intervals without log curves on the display indicate that no log was run. The following paragraphs discuss each component of the display format. 
Heading information (obtained from well completion reports or individual logs) consists of :

--well name;

--American Petroleum Institute (API) identifying number;

--surface location in terms of section (SEC), township (T), and range (R);

--total depth (TD) as measured by the driller; and

--elevation of either the kelly bushing (KB) or derrick floor (DF), points from which all well depths are measured.

The gamma-ray curve (GR) is expressed in standard API units. The GR scale range may differ from well to well, with variations in intensity affected by changes in borehole diameter. GR readings for recent wells have been corrected for this affect, with appropriate notations in the title block.

The spontaneous potential curve (SP), with a scale range of 0 to 200 millivolts (mv), has been expanded on some displays to 0 to $100 \mathrm{mv}$ to achieve more precise bed definition. Manual shifts and baseline drift have been removed. Inverse-reading SP, a result of the use of high salinity mud, has been reversed to make the SP appear normal.

The lithology column shows interpretive rock type and rock thickness in symbols explained in figure 2. The interpretation is my own and was arrived at by comparison of log response with descriptions of cores and drill-cuttings from various sample logs. This comparison provides a calibration of log response to rock type and allows more accurate discrimination of rock type and bed thickness than the use of sample logs alone. Minimum bed thickness in the display is limited to $10 \mathrm{ft}$ by the inability of the machine to plot symbols closer than one-tenth of an inch. Because of this limitation, many thin beds recognized in cuttings, cores, and logs are not shown. Two sets of unlabeled depth ticks are plotted, one on each side of the lithology column. On the left edge of the column each tick represents $100 \mathrm{ft}$ and on the right, $100 \mathrm{~m}$. The depth marks start at zero at the top of the column which represents the elevation of either the kelly bushing (KB) or derrick floor (DF).

The resistivity curve (RES), with logarithmic scale in ohms $\mathrm{m}^{2} / \mathrm{m}$, is one of two or three resistivity logs that are run. The shallow-reading resistivity log (usually the laterolog 8 ) is used in the display for maximum bed definition.

The speed of sound through rock (SONIC) is expressed by the next curve. The units are microseconds per foot. In some displays a "smoothing" function has been applied to the curve to eliminate spurious readings such as "noise" and cycle-skipping.

The bulk density curve (DENSITY), in grams per cubic centimeter, is obtained from the compensated gamma-gamma density log. The tool is sensitive to borehole size and changes in size (see differential caliper curve) and many readings are inaccurate. No corrections have been applied to this curve.

The differential caliper curve (DIFF. CALIPER) shows the size (in inches) of the borehole in excess of the bit size. Measurements are obtained from a 
two-arm caliper run in conjunction with the density or neutron logs. In an elliptical hole, the two-arm caliper is most likely to measure the maximum diameter of the hole.

\section{ACKNOWLEDGMENTS}

The discussions and encouragement of L. B. Magoon and his collaboration in the design of the display are gratefully acknowledged. Production of the displays has been accomplished by the efforts of J.R. Mitchell, L. Montgomery, R. Mohundro, and M. Wolfson, all of the PI Energy Services Section.

\section{REFERENCES}

Magoon, L. B., and Claypool, G. E., 1980, Vitrinite reflectance and $\mathrm{C}_{1}-\mathrm{C}_{7}$ hydrocarbon data for South Simpson No. 1 well, North Slope, Alaska: U.S. Geological Survey Oil and Gas Investigations Chart OC-92.

Tetra Tech, Inc., 1980, Summary geologic report fiscal year 1980, prepared by E. C. Guldenzopf and others, Houston, Texas. Unpublished report prepared for the U.S. Geological Survey, Office of National Petroleum Reserve in Alaska. 
Table 1. List of North Slope Alaska wells with displays being released in this series of five open-file reports. Numbers refer to map locations in figure $I$ and to display plate numbers.

WELL DISPLAYS FROM THE NORTHERN IPRA (Open-P1le 81-1033)
1. Avak - 2
2. East 81mpen - 1
3. East 81mpeon - 2
4. Tro Bay - 1
5. North S1mpson - 1
6. Simpson - 1
7. South Barrow - 1
8. South Barron - 2
9. Bouth Barrow - 4

1. East Oumal1k - I

2. East Topagoruk - 1

3. Krolak - 1

4. Kugrua - 1

1. Atigaru Point - I

2. Cape Halkett - 1

3. Drew Point - 1

4. East Teshekpuk - 1
10. South Barron - 6
11. Bouth Barrow - 7
12. Bouth Barrow - 8
13. Bouth Barrow - 9
14. South Barrow - 10
15. South Barrow - 11
16. South Barrow - 13
17. Bouth Barrom - 3
18. South Barrow - 16

19. Bouth Barrow - 12

20. Bouth Barrow - 14

22. South Barrow - 27

22. Bouth Barrow - 19

23. South Barrow - 20

24. South siupson - 1

25. Walakpa - 1

E6. Whert Dense -1

WELL DISPLAYS FROM THE WESTERN IPRA (Open-f11e 81-1032)
5. Meade - 1
B. South Meade - 1
6. Oumelik - I
9. Topegoruk - 1
7. Peard - 1
10. Tunalik - 1

WELL DISPIAYS FROM THE NORTHEASTERN NPRA

$$
\text { (Open-file 81-1034) }
$$
5. Fish Creek - 1
9. South Harrison Bay - 1
6. Ikpikpuk - 1
10. West Fish Creek - I
7. J. *. Dazton - 1
12. *. T. Foran - 1
8. Korth Kalikpik - 1

WELL DISPLAYS FROM THE SOUTHEASTERN NPRA (Open-file 81-1035)
1. Inigok - 1
2. Knifeblade - $2 A$
3. Isburne - 1
4. Seabee - 1
5. Square Lake - 1

6. Titaluk - 1

11. Umiat - ?

7. Uniat - 1

12. Umiat - 11

B. Umiat - 2

9. Umiat - 3

13. Wolf Creek - I

10. Umiat - 4

14. Wolf Creek - 2

15. Wolf Creek - 3

WELL DISPLAYS FROM THE EAST-CENTRAI YORTH SLOPE -

$$
\text { (Open-s11e 61-1036) }
$$
1. Aufeis - 2
2. Mn Creek - 1
3. Crandotand -1
4. Gubik - 1

5. Cubik - 2
6. Kemik - 1

7. Lupine - 1 


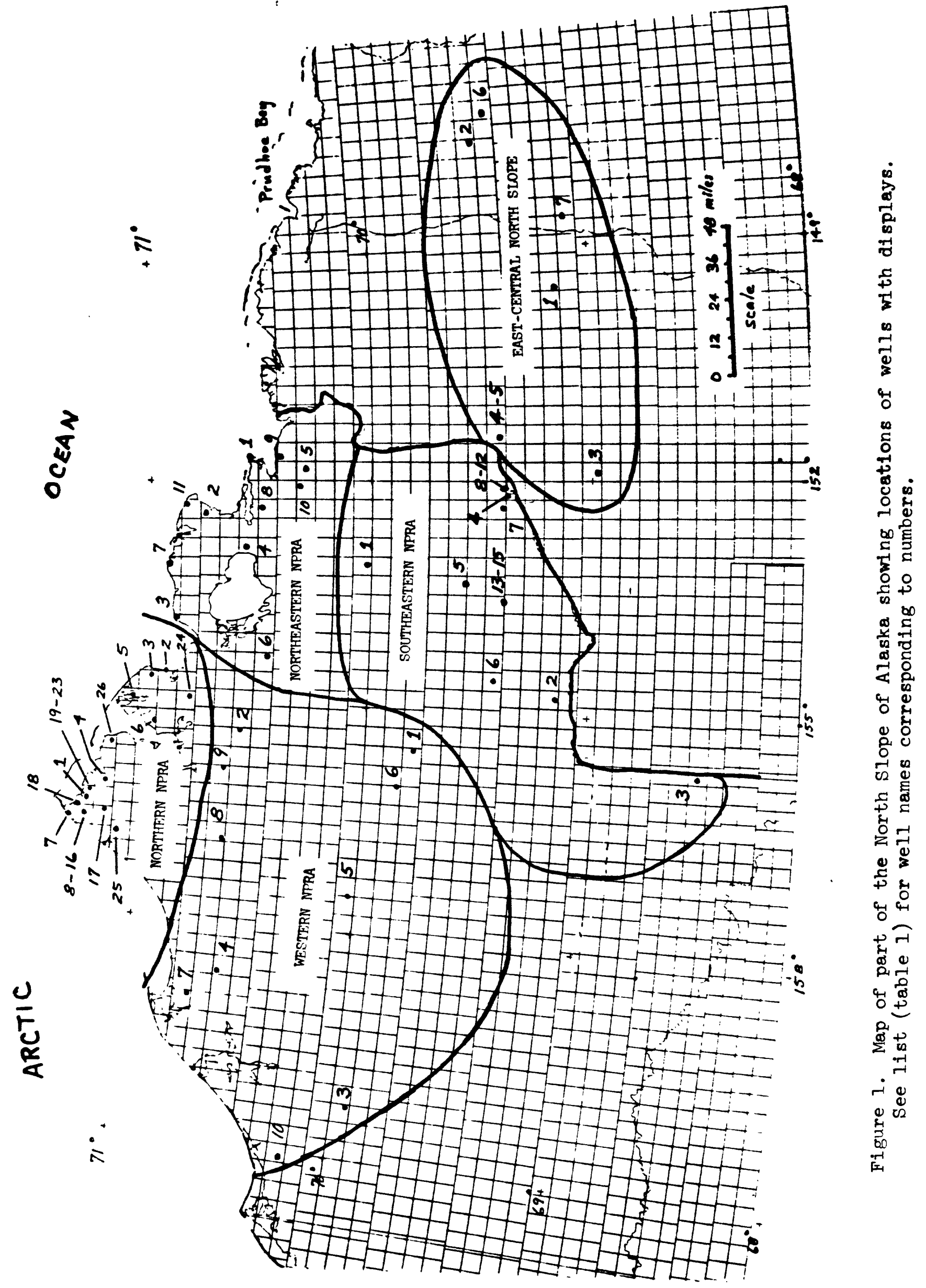



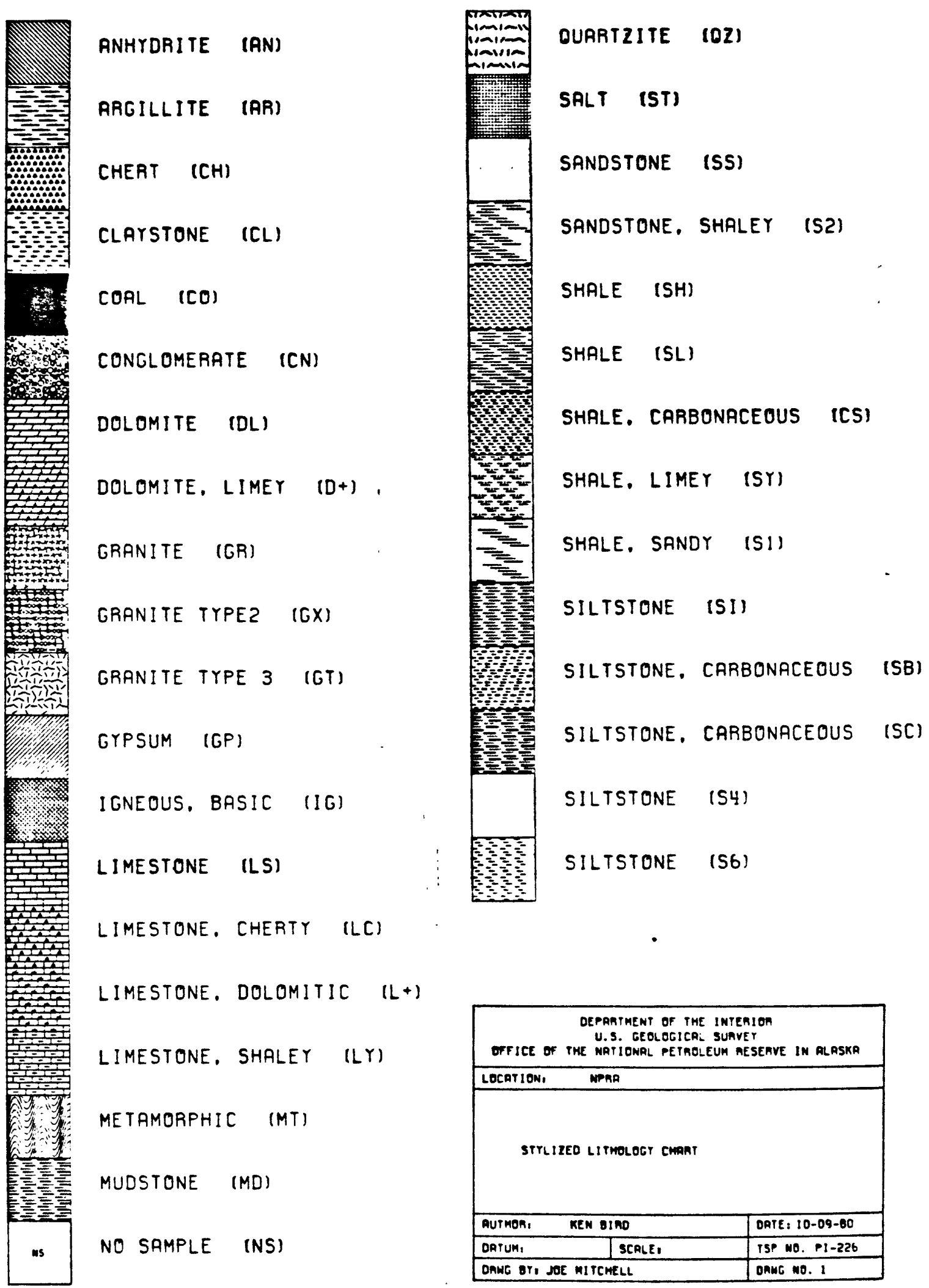

Figure 2. Symbols, name, and two-character code (In parentheses) currently used in the lithologic plotting program. 